\title{
Hybrid
}

Revue des arts et médiations humaines

\section{Preserving Theater Ephemera, from Programs to} Websites

\section{Iris Berbain and Cécile Obligi}

Translator. Saskia Brown

\section{(2) OpenEdition \\ Journals}

\section{Electronic version}

URL: https://journals.openedition.org/hybrid/1080

DOI: $10.4000 /$ hybrid. 1080

ISSN: 2276-3538

This article is a translation of:

Conserver l'éphémère du théâtre, du programme de spectacle au site web - URL : https:// journals.openedition.org/hybrid/1072 [fr]

\section{Publisher}

Presses universitaires de Vincennes

\section{Electronic reference}

Iris Berbain and Cécile Obligi, "Preserving Theater Ephemera, from Programs to Websites", Hybrid [Online], 1 | 2014, Online since 14 July 2014, connection on 12 April 2022. URL: http://

journals.openedition.org/hybrid/1080 ; DOI: https://doi.org/10.4000/hybrid.1080

This text was automatically generated on 12 April 2022.

Revue Hybrid 


\title{
Preserving Theater Ephemera, from Programs to Websites
}

\author{
Iris Berbain and Cécile Obligi
}

Translation : Saskia Brown

1 Nothing is more ephemeral than a theater performance; it is by definition unique. Yet it leaves traces of its existence, and these are preserved by the Performing Arts Department of the Bibliothèque nationale de France (BnF, French National Library). Some of these traces are particularly short-lived, for example, the information issued for the press and public about theater productions. Common, functional documents of this sort include the season's schedule, individual programs, brochures and leaflets, subscription forms, invitations, theater tickets, and press kits and cuttings, all of which exist in multiple copies for a brief period. Once they are no longer useful as publicity, they tend to be destroyed, and their life ends there, unlike documents which can be classed as artistic works, such as photographs and recordings of performances. The BnF has a long collection history in ephemera -and not solely in the sphere of the performing arts- due to the legal deposit system and thanks to private collectors. Some colleagues remember carefully salvaging tracts from May 1968 !

2 In the past few years, these ephemera have undergone a rapid shift, with e-newsletters replacing mailings, tickets going electronic, and the season's shows or press kits being made available on the websites of venues, companies and festivals. This change to a virtual medium calls for forward thinking, namely on how means and methods of collection, preservation, signaling and access will evolve for these documentary collections. All the more so since the websites which have largely replaced the previous forms of documentation are doubly ephemeral: web contents are by nature impermanent and informational material concerning productions is not preserved online any more carefully than were physical documents previously. However, a French law of 2006 providing for the legal deposit of the web mandated the BnF to collect and preserve French websites, which it does partly through automatic harvesting. It thus continues collecting ephemera, adding, for example, to the physical political tracts 
collected during election campaigns the websites of the different candidates during the same period.

3 In this article we intend to examine the breaks and continuities involved in archiving ephemeral documents in the performing arts, from collecting programs to harvesting French websites in the framework of the BnF's mandate. We shall address only "the most ephemeral ephemera," namely communication materials about performing arts productions. This excludes preparatory documents (which also disappear rapidly) and artistic documents such as photographs and audiovisual recordings.

First we shall explain why we preserve these ephemera. Then we shall describe how a collection of ephemeral documents is constituted, preserved and signaled. Lastly, we shall discuss the continuities and discontinuities involved in moving from a paper to a digital medium, or when the two co-exist.

\section{Why preserve a collection of ephemera?}

5 The first reason for preserving these documents is that the BnF is obliged to do so by law. The French Heritage Law provides that:

Printed, graphic, photographic, sound, audiovisual and multi-media documents, whatever the technique by which they were produced, published or disseminated, are liable to obligatory deposit, called legal deposit, if they are made accessible to the public. [...]

Software and databases are liable to legal deposit if they are made available to the public in a physical medium, whatever the nature of the medium.

Is also liable to legal deposit every sign, signal, writing, image, sound or message of whatever kind communicated to the public by electronic channels. ${ }^{1}$

6 Legal deposit originated in the Montpellier ordinance promulgated by Francis I in 1537. At the time it applied to printed books, but it has since been extended to other materials and media: prints, maps and plans in 1648, musical scores in 1793, photographs and sound recordings in 1925, posters in 1941, videograms in 1975, multimedia documents, software and databases in 1992, and lastly the web in 2006.

The ephemeral documents produced for performing arts productions clearly fall within these categories. However, the BnF's collections have never been constituted by means of the legal deposit system alone, and despite notable improvements, this scheme is always supplemented by librarians' acquisitions. Moreover, some of the ephemera generated by a production lie outside the limits defined by the law, for example the press clippings collected by theaters or companies for internal use, which are not for public consumption.

Quite apart from the BnF's legal obligations, ephemeral documents are important for research, being a rich source of information as yet too infrequently exploited by researchers. In the performing arts, they provide objective information on the history of a theater, a theater's director, an actor, an author or the different performances of a play. They also document all the people involved, showing how, for example, the author, director, set designer, costume designer, lighting designer, and actors were presented (prior to the Revolution actors were barely mentioned). By studying these ephemera, we can see new professions emerging or gaining favor: for example, in the wake of André Antoine, the director's role became more prestigious; and in the last few 
years the playwright's name has become more important; the set designer has gradually become simply a "designer," and so forth.

Hence ephemera not only tell us about theater history and theater trends, but also more generally about society. One could mention in this connection Livia Suquet's recent work on striptease, as reflected in the programs of shows. ${ }^{2}$ Ephemera contain an abundance of information on daily life and social practices, as conveyed, for example, by the price of tickets or by advertisements, which can take up a lot of space in theater programs. A whole history of advertising could be written on this basis, covering adverts for motor cars, storage space, tea-rooms, perfumes or fashion houses (which may dress one of the actresses). Sometimes one can even stumble upon a fully-fledged sponsoring system ahead of its time: the Fratellini brothers, for instance, received financial support from a toothpaste salesman. Theater programs also provide a window onto the history of cultural policy. This is particularly true of festivals: looking closely at the logos on communication materials can tell us something about how shows and cultural events were financed.

10 Although not made to last, ephemeral documents carry precise messages. The Moulin Rouge's programs are not like those of the Comédie-Française, and this is no less true today than it was a century ago. Programs convey the orientation of the theater's director, they are ideological. The programs of the Théâtre de l'ÆEuvre or the ThéâtreLibre, ${ }^{3}$ lavishly illustrated by famous names, contrast sharply with the austere programs of the Théatre National Populaire under Jean Vilar.

11 Ephemeral documents, in the form of programs and even more so of posters, help create a visual identity composed of a set of signs easily recognizable by the spectator. Studying posters from this point of view is extremely interesting. The posters at the entrance to theaters, on Morris columns or in the corridors of the subway construct a visual universe which affects the spectator and punctuates his or her movements around the town. Every theater tries to attract our attention. Seventeenth-century theaters used different colors, even when the posters' contents and graphics were almost identical: red for the Hôtel de Bourgogne, green for the Hôtel de la rue Mazarine, and yellow for the Opera.

12 These older posters have rarely been preserved and are absent from the BnF's Performing Arts Department's collections. The latter essentially date from the second half of the nineteenth century, particularly for the Théatre du Palais-Royal, whose posters, issued daily in black type on white paper are fragile because they were produced rapidly and cheaply, as one does for material not designed to last. Illustrated posters existed in the nineteenth century, but usually for cabarets and circuses rather than for the theater. A figure such as Sarah Bernhardt could afford to have costly posters designed by painters, but this was far from being the case for the majority of such material at the time. Most posters were actually very similar to each other, and hardly attracted attention. So theaters tried to get noticed through publicity ploys like mentioning how many performances the play had had so far. They used color -the Vieux-Colombier's green posters were immediately distinguishable from the Athénée's red ones or the orange of the Théatre Montparnasse under Gaston Baty- and also typography. Jacques Copeau and Gaston Baty developed a kind of "logo": the two doves for the Vieux-Colombier [literally: "Old-Dovecot"] under Jacques Copeau, and the heart and rose (evoking Elizabethan theater) under Baty. 
13 It is still important today for theater posters to be immediately recognizable. Yet strikingly few theaters, particularly variety theaters, make an effort in this respect. The poster is often a photograph from the show which aims at enticing the spectator. "High-brow" theater, on the other hand, owes it to itself to have its own visual identity and to hire well-known graphic artists. The graphic design and the presence of photographs are far from neutral choices. They prime the spectator in conveying a particular approach. Graphic artists are paradoxically keen to design theater posters, despite their ephemeral nature: being the official graphic designer for a theater is highly sought after.

These different types of ephemera deserve closer study. A history of performance programs has yet to be written (and programs in the form of fans or pillboxes doubtless reserve not a few surprises), and the history of theater posters would benefit from more in-depth study. There are few academic research projects at present devoted primarily to ephemera. ${ }^{4}$

15 Although the ephemera preserved by the BnF's Performing Arts Department are by nature difficult to circumscribe, they are quantifiable. The collection consists of some 80,000 theater posters, and more than 56,000 sets of press cuttings, ${ }^{5}$ which have mostly been assembled by the Department itself. The programs, tracts, brochures, theater tickets and communication materials collected by librarians since the 1970 s and classified by place, theme or personality would occupy 800 linear meters (over two thousand six hundred linear feet) if put end to end. ${ }^{6}$ The term "Press" here covers a number of different elements: the cuttings made in the Department itself (to constitute files of cuttings), the press kits (sent by theater companies to journalists to advertise their shows), and lastly the press reviews gathered by theaters or companies. Then there are also theaters' newsletters, subscription forms, invitations to the presentation of forthcoming productions, and all the other documentation produced for a venue's activities such as exhibitions, concerts or miscellaneous events. And this does not take into account the thousands of web pages devoted to the show.

\section{Creating, preserving and signaling a collection of ephemera}

The BnF's Performing Arts Department's collection of ephemera started with Auguste Rondel's private collection (1858-1934). This banker and private collector, who was a passionate theater-lover, assembled a substantial collection of documents on all aspects of the performing arts, following in the footsteps of the great eighteenth- and nineteenth-century collectors like the Count of Pont-de-Veyle, the Duke of La Vallière, or the Marquis of Soleinne. Rondel donated his collection to the French State in 1920, and it eventually ended up in the Bibliothèque de l'Arsenal from which the "theater collections" were removed in 1976 to form the Performing Arts Department. They comprised 400,000 documents, classified into thematic series (theater, dance, puppetry, songs, and so forth). This type of classification, and probably of collecting, was typical of collectors at the time. Auguste Rondel had decided on a thematic approach, independently of the medium or the nature of the document. Thus all the information about a particular playwright was held in the same place: his or her complete works, different editions of individual works, performance programs and tickets, studies on the works or the author, press cuttings on a production or on the author. Ephemera 
were thus mixed in with valuable editions of the plays. This mode of organization, in which elements are inserted as they are collected, is feasible for a relatively small private collection, but quite impossible on the scale of a national library. The BnF therefore chose a classification method based on library and information science, in which documents are classified according to their medium and format, providing optimal conditions for storage and preservation.

Today, the ephemeral documents collected by the BnF's Performing Arts Department are stored separately and classified by theater, festival and company. Within these categories the documents are then classed by season, and within each season, by theater production. Given the large quantities of material received under "theater," this series is further sub-divided, geographically, into three series: Paris, Ile-de-France and provinces. The fact that ephemera are now kept separate shows both the professionalism of the preservation policies and the greater attention paid to this type of document.

The collection receives new material throughout the year, primarily through the legal deposit scheme. There is often a peak at the beginning of the theater season. The documents arrive first at the BnF's "compendia" section (the service des recueils), which redirects them to the Performing Arts Department. Librarians regularly request supplementary materials directly from theaters, which willingly comply, but not necessarily due to heritage conservation concerns: often a theater needs to do a clearout when, for example, the theater's director changes or a theater closes. When the Théatre du Tambour-Royal in Paris closed, in 2011, the Department received an important gift of ephemera (particularly posters).

Ephemeral documents are not always treated with much care, no more so in their production than later in their existence. Some arrive in very bad condition, often after being stored in places harmful to their conservation, like the cellars or attics of theaters (or of private homes). Many of the posters received are printed on low-quality paper, and arrive literally in pieces. A restoration program exists for these.

These ephemera are described in the BnF's online catalogues. ${ }^{7}$ Some have been digitized and can be found online in the BnF's Digital Library, Gallica. We should also mention the sumptuous collection of music-hall programs from the Rondel collection. All those corresponding to the First World War period have been digitized in the context of the Europeana 14-18 program. ${ }^{8}$ One can consult, for instance, all the programs from the Ba-ta-clan for the years 1914-1918.

21 The BnF's collections of ephemera have grown significantly, and diversified, in the past few years, due to changes in the deposit legislation to include the Web. The French Heritage Law explicitly requires collecting to be as exhaustive as possible. This was already a near-impossible task for traditional media, and it is absolutely impossible in the case of collecting websites. We had to make choices in order to comply with the law, while also remaining within the limits of what is reasonable and practicable. The BnF's mandate extends only to French websites (thus excluding sites in foreign languages on French heritage, for example). Website collection works in the following way: a robot collects data from a list of websites identified as French. It downloads all the pages it visits, in other words, it "harvests" the web. Unlike the other types of legal deposit mentioned above, this "deposit" involves an automatic process of collecting. Website editors have no obligation other than not to obstruct the robot and to assist the process where necessary (by supplying technical information). Inversely, the robot 
itself needs no authorization, and no prior consultation with website editors is required.

It was decided to combine two types of collecting. First, "broad" web harvesting, carried out once a year, which collects information contained on home pages, and sometimes on pages one, two or three clicks deeper, depending on the site. It results in an annual snapshot of French domain websites. BnF librarians check the quality and coverage of the results. Secondly, there are targeted harvests of certain sites chosen for their contents. This second type of collecting corresponds to acquisitions in other media. The librarians make a list of the websites on which the robot will concentrate more particularly, and into which it will delve more deeply. The rate of its capture can be programmed, and can be as much as once a day for sites which require it (for example, major national dailies).

The results of these captures are called "Web Archives," which can be consulted in the BnF's reading rooms using a specific application. French legislation does not permit these archived contents to be made available over the internet; a regulation of 2011 provides that only authorized users in the BnF's Research section may have access.

Four major types of ephemeral documents relating to the performing arts are collected. First, due to the daily capture of the national and regional press, archives of performing arts news from the major media can be constituted, for example from Le Monde at http://www.lemonde.fr, Télérama at http://www.telerama.fr/scenes, the culture pages of a pure player ${ }^{9}$ such as Mediapart (http://www.mediapart.fr), and also from performing arts blogs on the websites of the major dailies. Broad superficial harvesting provides a snapshot of the major French theaters at a particular time. It is interesting, for example, to see how the website of the Théatre des Célestins in Lyon has developed over the years. Selective harvesting, by contrast, can capture sites which leave few traces, such as the ephemeral site of the "Nuit blanche," which has been preserved from its earliest years. This targeted harvesting ensures that essential and lesser-known theater sites, but also sites on puppetry, circus art, mime and street theater are archived. It also provides continuity for the collections: a dozen websites on particular performance venues and individuals were selected for in-depth archiving in 2013 because the BnF already holds a rich archival collection on them. For example, the dancer Carolyn Carlson's website, http://www.ccn-roubaix.com, is a useful complement to the notebooks, notes, photographs and audiovisual recordings already donated to the Performing Arts Department. Lastly, video captures (from the Daily Motion site http://www.dailymotion.com/fr) are carried out annually, in order to archive recordings of productions or presentations of forthcoming plays which are not necessarily found on theaters' websites.

\section{Physical versus digital media: continuity and change}

The shift from traditional analog media to digital media has a number of consequences for ephemeral documents. The changes are at first sight more striking than the continuities, for the observer and user.

The shift to a new, intangible medium for these documents endorses the absolutely false idea that they are easier to manage in this form. Whereas the document itself may be virtual, its long-term storage and preservation relies on computer servers which take up space (and cost money). Additionally, this move to digital documents involves a 
change of scale which affects our relation to the collection. The Performing Arts Department receives yearly more than 1,000 posters and more than 8,000 other communication documents (a mixture of programs, press kits, and other miscellaneous papers). Meanwhile, the legal deposit of the web collects almost 100 terabytes a year, corresponding to hundreds of thousands of files of different types. This electronic collection has expanded so greatly that we need different tools to evaluate its size.

Ephemeral collections have also become more comprehensive as a result of the shift to electronic formats. When one wished to link two physical documents (for example, two programs of the same play staged in two different theaters), a long and meticulous process was required. With hypertext links on web pages, connections can be made without any human intervention. Documents are thus much better contextualized, and the reader's experience is greatly improved overall.

The information provided is thus much richer when in virtual form. The ease of uploading different sorts of materials in larger volumes encourages the use of more photos, recordings and interviews. Rather than choosing one or two photos to illustrate a printed program, websites can have whole photo albums devoted to a play or an author. The Théâtre de la Colline in Paris, which builds substantial online portfolios for each of its plays, is a good example of these possibilities.

Not only are there infinitely greater quantities of electronic ephemeral documents, which are also more varied, but their source has changed. Their physical equivalents, however short their lifespan, were produced by recognized authorities and, in the performing arts, often by specialists. Press kits and press clippings were drawn almost exclusively from official sources such as the daily national and regional press, and the specialized press. Also, since human agents chose the material manually, the selection was limited, relatively unsystematic and not neutral. By contrast, the web harvesting prescribed by the legal deposit scheme takes in, for example, the blog of Armelle Héliot, a well-known critic who works for the national daily Le Figaro, but also the blogs of nonspecialists and enthusiasts. It even gathers internet users' comments, regardless of their content or quality. The voice of amateurs and unknown individuals can thus be preserved, giving us access to what is particularly elusive, and which historians have the most difficulty capturing, namely the opinion of the "average person."

The sheer bulk of ephemera collected in the context of the legal deposit of the web immediately generates the problem, for librarians and readers, of how to signal and how to find documents. Paper-based theater programs and press packs can almost all be signaled; for a few thousand documents it is quite possible to give at least a place and a date, and often one can provide further information about the play. However, this is quite impossible, even in the briefest form, for the hundreds of thousands of files harvested from the web. The volume of ephemeral documents collected increases yearly, due to the increased size of the web (in 2012 the French web was estimated at 7 million sites) and the enhanced technology of the robots, which collect more and more data. At present the main way of accessing this information remains the URL, that is, the website's address. In order to retrieve a piece of information, one has to know the website on which it was published, and know the website's URL, which may have changed or no longer exist. In the last fifteen years, many websites and even official theater websites have changed address. One has to have detailed knowledge of the context of production of a piece of ephemeral information in order to have access to it. 
Searches by word within the web archives only work for a tiny part of these, and have given poor results so far.

31 Compared to their paper counterparts, the information provided by electronic ephemeral documents is therefore richer, more varied, more complete, better contextualized and better cross-referenced; but it is also more diluted, more difficult to find, more difficult to make known, and in a sense flattened out. The potentialities have increased exponentially, but so too has the difficulty of exploiting them!

Although the changes resulting from the shift to digital media are immediately visible to the observer and have partly overturned established practice, this should not blind us to the continuities. In his book Le Théâtre et le public à Paris sous Louis XIV, ${ }^{10}$ Pierre Mélèse lists the methods used to publicize a show. He mentions posters, orators, advertisements in gazettes for the season's plays, press reviews and press articles. Clearly, most of these methods have remained unchanged, even if they are supplemented today by other more modern ones.

33 Additionally, the shift to electronic formats has not completely changed the nature of the information communicated. On the websites of certain theaters one can sometimes find the "ready for press" document in PDF format which was given to the printers for the paper version. The layout of the Théâtre Antoine's auditorium was printed on its programs in the first half of the twentieth century, and it is still there today, but online -and admittedly with the added option of a virtual visit. But the information communicated is basically the same.

34 There is also continuity in the collection methods for ephemeral documents, combining a broad inclusive strategy with a more subjective and individualized one. Through the legal deposit system we receive armfuls of programs, but we also follow up individual theaters; similarly, the legal deposit of websites combines very extensive but superficial web-harvesting with targeted collecting from websites chosen by librarians. The relation between volume and detail, objectivity and subjectivity remains the same.

Lastly, it is noticeable that regardless of the medium, ephemeral documentation elicits similar types of behavior. Just as a theater's new director often throws out the documentation produced by the preceding one, so the website is often redesigned. Material archives, and particularly ephemera, are sometimes just thrown away. Sometimes, luckily for their posterity, they are donated to the BnF's Performing Arts Department. For example, on Didier Bezace's departure from the Théâtre de la Commune d'Aubervilliers in 2013 the Department received a certain volume of documents. Similarly, it is common to overwrite a website or completely transform its design. But just as some theaters scrupulously preserved the material ephemera produced by their predecessors, at times to the extent of creating genuine archival departments in their theater, so certain websites methodically archive, season by season, all the documentation produced, including ephemera. However, this concern for archives is often proportional to the means at the theater's disposal and hence to the size of the establishment: the larger national theaters (the Odéon or the ComédieFrançaise, for instance) pay more attention to their ephemera than do smaller structures. There is still too little awareness overall, and ephemera, whether physical or virtual, are always at the mercy of changes of personnel.

36 Ironically, a theater sometimes tries to find its previous ephemera in order to create new ones. This occurred when the Théâtre des Champs-Elysées wanted to look through its old posters, and turned to the BnF's Performing Arts Department. ${ }^{11}$ Today, the 
wallpaper of the theater's website -another ephemeral object- is composed of a digitized montage of some of its old posters.

Ephemera incarnate vital aspects of the performing arts for posterity, and yet they remain undervalued and rarely preserved, outside of the BnF's Performing Arts Department. The material collected through the legal deposit scheme, together with the acquisitions made by librarians in the Department, provide a rich source of information as yet too infrequently exploited by researchers.

The changes undergone by ephemeral documents on the performing arts, particularly in the last decade, have not affected the uses to which they are put so much as the practices of librarians and readers. Whether the medium is physical or virtual, the uses are identical when the ephemera are "alive". Afterwards, virtual ephemera are more efficiently collected but less accessible, and the reader can find his or her way more easily in the material collections of ephemera than in the electronic ones. The vertiginous quantity of such documents is at once thrilling and disorientating. One can compare, for example, the moderate number of press cuttings ${ }^{12}$ on the scandal caused by Romeo Castellucci's production Sul concetto di volto nel figlio di Dio at the Théâtre de la Ville in 2011 with the tidal wave of reactions (so large as to be unquantifiable) on the web, which was archived through the legal deposit system.

We have yet to find ways of signaling links between physical and virtual ephemera, the challenge being to ensure the comprehensiveness of our collections, for which new uses will doubtless be invented.

\section{BIBLIOGRAPHY}

MAZzA Vincenzo, Jean-Louis Barrault-Albert Camus. L'enjeu de L'État de siège. Entre adaptations et collaborations, le travail d'un capocomito français $d u X^{e}$ siècle, Doctoral Thesis in Arts and Human Sciences, Nanterre, Paris X Nanterre University, 2013.

SUQUET Livia, Les Dessous de la Belle-Époque, les origines du strip-tease, Master 2 Dissertation supervised by Romain Piana, Paris, Theater Studies Departement, Paris 3-Sorbonne Nouvelle University, 2013.

TAMAGNE Florence, "Le 'crime du Palace': homosexualité, médias et politique dans la France des années 1930," Revue d'histoire moderne et contemporaine, no. 53-4, 2006, p. 34-62.

TERRIER Agnès, Le Billet d'opéra: petit guide, Paris, Opéra national de Paris/Flammarion, 2000.

\section{NOTES}

1. Article L131-2.

2. Livia Suquet, Les Dessous de la Belle-Époque, les origines du strip-tease, Master 2 Dissertation supervised by Romain Piana, Paris, Theater Studies Departement, Paris 3-Sorbonne Nouvelle University, 2013. 
3. The Théatre-Libre's programs from the 1890s are famous for their illustrations by Henri de Toulouse-Lautrec.

4. There is one notable exception: Agnès Terrier, Le Billet d'opéra: petit guide, Paris, Opéra national de Paris/Flammarion, 2000. Other works make extensive use of ephemera, but the latter are not the prime object of the research. See, for example: Vincenzo Mazza, "Jean-Louis Barrault-Albert Camus. L'enjeu de L'État de siège. Entre adaptations et collaborations le travail d'un capocomito français du $\mathrm{xx}^{\mathrm{e}}$ siècle," Doctoral Thesis in Arts and Human Sciences, Paris X-Nanterre University, 2013 ; Florence Tamagne, "Le 'crime du Palace': homosexualité, médias et politique dans la France des années 1930," Revue d'histoire moderne et contemporaine, no. 53-4, 2006, p. 34-62. This article is about the theater manager Oscar Dufrenne (1875-1933). It draws on the BnF Performing Arts Department's collection of theater programs.

5. This number includes the press cuttings from the Rondel collection, the Supplement to the Rondel collection (classed under shelf mark Rsupp), and the documents which follow on from Rsupp, at shelf mark Sw.

6. These are kept at shelf mark WN.

7. [Online] mainly at http://catalogue.bnf.fr/ and secondarily at http:// archivesetmanuscrits.bnf.fr/ [Accessed: 20 December 2013].

8. [Online] http://www.europeana-collections-1914-1918.eu [Accessed: 20 December 2013].

9. "Pure players" are newspapers which exist only on the Web and do not have a hard-copy equivalent.

10. Published in 1934.

11. In 2013, for the theater's centenary.

12. Classed under shelf mark WNA-161 (2011-2012).

\section{ABSTRACTS}

Theater performances are ephemeral, being by definition unique. Yet they leave traces of their existence, which are preserved by the Performing Arts Department of the Bibliothèque nationale de France (French National Library). Some of these traces are particularly short-lived, such as the documentation issued for the press and public composed of programs for individual plays or for the season's productions, brochures and leaflets, subscription forms, invitations, tickets, and press kits and cuttings. In the last few years, there has been a shift to electronic documentation, using another short-lived carrier, the web. This article explores the continuities and discontinuities in archiving performing arts ephemera, from archiving theater programs to harvesting the web in the context of the mandate received by the Bibliothèque nationale de France (French National Library) for the "legal deposit of the web."

INDEX

Keywords: electronic heritage, legal deposit, posters, programs, websites 


\section{AUTHORS}

\section{IRIS BERBAIN}

Iris Berbain is a curator in the Performing Arts Department of the Bibliothèque nationale de France (French National Library), and Head of the Iconography and Documentation section. She trained as an archivist and paleographer, and completed a doctoral thesis, supervised by JeanMichel Leniaud, at the Ecole des Chartes on the set designer Émile Bertin: Le Peintre aux vingt âmes diverses: Émile Bertin (1878-1957), décorateur de théatre. She is continuing her research in the form of a doctoral thesis at the École Pratique des Hautes Etudes (Paris, EPHE).

\section{CÉCILE OBLIGI}

Cécile Obligi is a curator in the Performing Arts Department of the Bibliothèque nationale de France (French National Library), and a coordinator for digital issues. She was awarded a DEA from Paris 1 University (The Institute for the History of the French Revolution) and is the author of a biography of Maximilien Robespierre (Paris, Belin, 2012). 